\title{
Aspects of nitrogen metabolism in coffee plants
}

\author{
Maria Luiza Carvalho Carelli ${ }^{1 *}$, Joel Irineu Fahl ${ }^{1}$ and José D. Cochicho Ramalho
}

${ }^{1}$ Centro de Pesquisa e Desenvolvimento de Ecofisiologia e Biofisica, Instituto Agronômico, CP 28, 13001-970, Campinas, SP, Brasil; ${ }^{2}$ Centro de Ecofisiologia, Bioquímica e Biotecnologia Vegetal, Instituto de Investigação Científica Tropical, Av. da República, Quinta do Marquês, 2784-505 Oeiras, Portugal. *Corresponding author: carelli@iac.sp.gov.br

Coffee plants are highly N-demanding plants. Despite the importance of N nutrition for the development, acclimation and yield of coffee plants, there are few reports concerning $\mathrm{N}$ metabolism in this species. In this review, our intention is to summarize the information available in the literature and to point out the influence of environmental conditions on $\mathrm{N}$ assimilation, as well as comment and discuss some apparently contradictory results and raise and enlighten queries about $\mathrm{N}$ assimilation in coffee plants.

Key words: Coffea, irradiance level, nitrate reductase, nitrogen fertilization, oxidative stress, photoinhbition, photoprotection, photosynthesis.

Aspectos do metabolismo de nitrogênio em plantas de café: Plantas de cafédemandam grandes quantidades de N. Apesar da importância da nutrição nitrogenada para o desenvolvimento, aclimatação e produtividade de plantas de café, são poucos os trabalhos sobre o metabolismo de $\mathrm{N}$ nesta espécie. A intensão desta revisão é sumarizar a informação disponível na literatura e discutir a influência das condições ambientais na assimilação de $\mathrm{N}$, assim como comentar e discutir alguns resultados aparentemente contraditórios e levantar e destacar perguntas sobre a assimilação de $\mathrm{N}$ em plantas de café.

Palavras-chave: Coffea, estresse oxidativo, fertilização nitrogenada, fotoinibição, fotoproteção, fotossíntese, nível de irradiância, redutase do nitrato.

\section{INTRODUCTION}

Nitrate is the main inorganic nitrogen compound available to most cultivated plants grown under field conditions. The reduced forms of nitrogen $(\mathrm{N})$ applied as fertilizers undergo rapid nitrification under normal conditions of soil management. In natural soils, nitrate is usually present in the soil solution at concentrations that can be lower than 1 mol. $\mathrm{m}^{-3}$, while in agricultural soils concentrations reach values as high as $20 \mathrm{~mol}^{-3} \mathrm{~m}^{-3}$ in consequence of $\mathrm{N}$ fertilization (Andrews, 1986).

Within the plant, nitrate must be first reduced to ammonium before being assimilated into amino acids. Nitrate absorbed by plants is reduced to nitrite by nitrate reductase (NR) in the cytosol of cells. Nitrite is subsequently reduced to ammonium by nitrite reductase in the plastids, and am- monium is then incorporated into amino acids. NR probably represents the rate-limiting step in nitrate assimilation and can be used as a marker to estimate the capacity of plant roots and shoots to assimilate external N (Beevers and Hageman, 1980; Oaks, 1994). In fact, this enzyme is considered a major limiting factor for growth, development and protein production in plants. Therefore, the regulation of nitrate assimilation has been the focus of intensive research work aimed at improving the efficiency of this process and thereby enhance agricultural productivity through intervention in this growthlimiting process (Solomonson and Barker, 1990).

The fact that coffee plants are highly N-demanding plants has been known since the early 1950s. N requirement increases with plant age especially at the beginning of grain production (Catani and Moraes, 1958). If there are no

\footnotetext{
Abbreviations - $A$, net photosynthetic rate; $A_{\max }$, photosynthetic capacity at $\mathrm{CO}_{2}$ and light saturating conditions; $C 16: 0$, palmitic acid; $C 18: 3$, linolenic acid; ${ }^{3}$ Car triplet state of $\beta$-carotene; chl, chlorophyll; ${ }^{1} \mathrm{chl}$, singlet state of $c h l ;{ }^{3} \mathrm{chl}{ }^{*}$, triplet state of $c h l ; c y t$, cytochrome; $D E P S$, de-epoxidation state; $F_{\mathrm{o}}$, minimal fluorescence of antennae in dark-adapted leaves; $F_{\mathrm{v}} / F_{\mathrm{m}}$ and $F_{\mathrm{v}}{ }^{\prime} / F_{\mathrm{m}}{ }^{\prime}$, photochemical efficiency of $P S I I$ in dark-adapted leaves and under photosynthetic steadystate conditions, respectively; $\mathrm{H}_{2} \mathrm{O}_{2}$, hydrogen peroxide; $L H C$, light harvesting complexes associated with photosystems; $J_{\text {max }}$, electron transport capacity; $\mathrm{NR}$, nitrate reductase; NRA, nitrate reductase activity; $\mathrm{O}_{2}{ }^{-}$, superoxide anion radical; ${ }^{1} \mathrm{O}_{2}$, singlet state of oxygen; $O E C$, oxygen-evolving complex from $P S I I$; 'OH, hydroxyl radical; $P_{680}, P S I I$ reaction centre; $P P F D$, photosynthetic photon flux density; $P S I$ and II, photosystem I and II, respectively; $Q_{\mathrm{A}}$, quinone A; $q_{\mathrm{E}}$, "high-energy" quenching; $q_{\mathrm{NP}}$, non-photochemical quenching; $q_{\mathrm{P}}$, photochemical quenching; TFA, total fatty acids; $V_{\text {cmax }}$, maximum carboxylation activity; $\Phi$, quantum yield of photosynthesis; $\phi_{\mathrm{e}}$, estimation of the quantum yield of photosynthetic electron transport.
} 
limiting factors present, an adequate $\mathrm{N}$ supply will promote rapid plant development, specifically through the increase in number of leaf pairs and plagiotropic branches per plant, number of nodes per branch, and number of fruiting nodes and flowers per node, which, taken together, are associated with higher yields in coffee (Malavolta, 1986; Willson, 1985; Fahl et al., 1994, Nazareno et al., 2003). In addition, N is a decisive factor for the protection of coffee plants against photoinhibition of photosynthesis when plants are exposed to high irradiances, since it promotes the triggering and reinforcement of protective mechanisms (Nunes et al., 1993; Fahl et al., 1994; Ramalho et al., 1999, 2000).

\section{Light influence on nitrate assimilation}

Before examining the effects of light on nitrate assimilation of coffee plants, some general considerations are appropriate. Coffea sp evolved as an evergreen understory tree in the African tropical forests, exhibiting typical features of shade-adapted plants. Coffee cultivation in agroforestry systems is a common practice in Latin America, but in Brazil, the cultivation under full sunlight is the prevailing system. This latter agricultural system has been highly successful due to the high acclimation capacity of coffee plants to different irradiance regimes, involving changes in physiological, anatomical and ultrastructural characteristics (Voltan et al., 1992; Fahl et al., 1994, Ramalho et al., 1997, 1999, 2000).

The high ability of coffee plants to acclimate to different irradiance regimes might be the cause, at least in part, for the conflicting data in the literature concerning the influence of light on carbon assimilation (Fahl et al., 1994; Carelli et al., 1999, 2001; Andrade Netto, 2005; for review see Da Matta, 2004) and $\mathrm{N}$ assimilation, as will be described below. These pathways are highly coordinated in higher plants and the metabolic interactions between them involve several steps of reciprocal control (Noctor and Foyer, 1998; Kaiser and Huber, 2001). The photosynthetic capacity of coffee leaves, in response to changes in irradiance levels, is positively correlated with their N content (Fahl et al., 1994; Carelli et al. 1999; Ramalho et al., 2000; Andrade Neto, 2005; Carelli and Fahl, 2005), because most of the $\mathrm{N}$ is used in the synthesis of photosynthetic apparatus components (Evans, 1989). Furthermore, recent evidence indicates that leaf NRA is positively correlated with carbon assimilation in coffee plants growing under different irradiances regimes (Andrade Netto, 2005; Carelli and Fahl, 2005).

Light is one of the most important environmental factor involved in the regulation of NR (Beevers and Hageman,
1980, Lillo, 1994). Light stimulates de novo synthesis, as well as the activation of NR at the protein level (Lillo, 1994). Like many others enzymes, a circadian rhythm in NRA has been reported for several species, increasing during the light hours, with a peak about noon, and decreasing during the dark period. In this respect, Meguro and Magalhães (1982) found that light induced increased leaf NRA in young coffee leaves, reaching maximum values between two and six hours after the beginning of the illumination period, and decreasing thereafter until the end of dark period.

Subsequently, it was shown that leaf NRA of coffee decreases continuously during the light period and increases during the night (Cordeiro et al., 1984; Alves et al., 1985; Carelli, 1987; Queiroz et al., 1993b; Ramalho et al., 1999). Results obtained by Alves et al. (1985) showed similar NRA behavior in leaves of 6-month-old plants, but not in 12-month-old plants. The latter exhibited enhanced NRA during the light hours and decreased during the night hours, as initially proposed by Meguro and Magalhães (1982). More recently it was observed that leaf NRA assayed in plants grown under full sunlight (1300 $\mu \mathrm{mol} \mathrm{m} \mathrm{m}^{-2} \cdot \mathrm{s}^{-1}$ at noon) decreased during the daytime, while leaf NRA in plants grown under $50 \%$ of full sunlight ( $600 \mu \mathrm{mol} \mathrm{m}{ }^{-2} \cdot \mathrm{s}^{-1}$ at noon) was initially low, peaked around noon and decreased at the end of afternoon (Andrade Netto, 2005), thereby showing the classical pattern observed in others species.

Hence, the assumption that leaf NRA in young coffee plants decreases continuously during the light period must be carefully considered. In experiments showing this behavior (Cordeiro et al., 1984; Alves et al., 1985; Carelli, 1987; Queiroz et al., 1993b), the leaf NRA was evaluated in plants acclimated to moderate irradiance $\left(500-800 \mu \mathrm{mol} \mathrm{m} \mathrm{m}^{-2} \cdot \mathrm{s}^{-1}\right)$ and transferred to a growth chamber, under approximately $85 \mu \mathrm{mol} \mathrm{m}{ }^{-2} \cdot \mathrm{s}^{-1}$ of irradiance level, for several days prior to when measurements were carried out. This latter irradiance level may be considered very low even for shade-adapted coffee plants, which show photosynthetic light saturation at around $300 \mu \mathrm{mol} \mathrm{m}{ }^{-2} \cdot \mathrm{s}^{-1}$ and a light compensation point of about $31 \mu \mathrm{mol} \mathrm{m}{ }^{-2} \cdot \mathrm{s}^{-1}$ (Fahl et al., 1994). It has been shown that carbon assimilation strongly decreases in leaves of coffee plants grown under irradiance levels below photosynthetic light saturation (ca. $290 \mu \mathrm{mol} \mathrm{m}{ }^{-2} \cdot \mathrm{s}^{-1}$ ) in relation to moderate irradiance (ca.700 $\mu \mathrm{mol} \mathrm{m}^{-2} \cdot \mathrm{s}^{-1}$ ) (Carelli et al, 1999; Carelli and Fahl, 2000, 2005; Andrade Netto, 2005). Photosynthesis is required for NRA and even under continuous high light $\mathrm{NR}$ becomes inactive when $\mathrm{CO}_{2}$ is absent (Kannangara and Woolhouse, 1967; Kaiser and Huber, 2001). In fact, leaf 
NRA and carbon assimilation in coffee leaves are highly coordinated in response to the irradiance regime, both processes decreasing under low irradiance (Carelli and Fahl, 2005). Therefore, it is possible that the previously reported decay in leaf NRA during the light period could be due to photosynthetic limitations caused by low irradiance levels. At the other extreme, the decay in leaf NRA during daylight observed when plants were first acclimated to low irradiance $\left(150 \mu \mathrm{mol} \mathrm{m}{ }^{-2} \cdot \mathrm{s}^{-1}\right)$ and then transferred to full sunlight (1500$1700 \mu \mathrm{mol} \mathrm{m} \mathrm{m}^{-2} \cdot \mathrm{s}^{-1}$ at noon), appears to be related to impaired photosynthesis (Ramalho, 1999).

Nevertheless, besides the high acclimation ability to different irradiance regimes, coffee plants apparently maintain the genetic characteristics of a shade-adapted species with regard to nitrate assimilation. Leaf NRA is always higher in plants grown under $50 \%$ full-sunlight than in plants under full sunlight (Faleiros et al., 1975; Carelli et al, 1990b; Carelli and Fahl, 2000; Andrade Neto, 2005). The effect of irradiance regime on root NRA will be discussed in the next section.

Undoubtedly, the physiological and biochemical role of light in nitrate assimilation, as well as its interaction with photosynthesis, is still not very clear for coffee plants and the subject requires more extensive research.

\section{Partitioning of NRA between leaves and roots}

Nitrate is easily transported in the plant and can be assimilated both in leaves and roots. The partitioning of nitrate reduction between roots and shoots may vary with plant species, age and environmental factors. In most herbaceous plants nitrate reduction occurs predominantly in the leaves (Andrews et al., 1986; Gojon et al., 1994), while studies on nitrate concentration in xylem sap exudates and in vivo and in vitro NRA showed that woody species reduce most of their nitrate in the roots (Cruz et al., 1991, 1993; Gojon et al., 1991; Lee and Titus, 1992; Thomas and Hilker, 2000).

Coffee plants present high potential for nitrate assimilation in leaves as well as in roots. Nevertheless, there is a lot of controversy about this subject in the literature. Some reports have shown higher NRA in leaves (Carelli et al., 1990a; Da Matta et al., 1999; Amaral et al., 2001), and others in roots (Carelli and Fahl, 1991, Queiroz et al., 1991, 1993a).

It is generally accepted that distribution of nitrate reduction between roots and shoots is mainly dependent on the ability of the root to export nitrate to the shoots (Radin,
1978, Smirnoff and Stewart, 1985; Gojon et al., 1994). Under high nitrate availability, roots of young coffee trees showed high capacity to export nitrate to the shoots. After supplying $15 \mathrm{~mol} . \mathrm{m}^{-3} \mathrm{NO}_{3}{ }^{-}$to nitrogen starved intact plants, both roots and leaves accumulated similar nitrate levels; at the same time, NRA was rapidly induced in roots and leaves in a similar way (Carelli and Fahl, 2005). Such evidence is consistent with the composition of nitrogenous compounds in the xylem sap exudates of coffee seedlings reported by Mazzafera and Gonçalves (1999). These authors observed that seedlings fed with Hoagland's solution presented nitrate- $\mathrm{N}$ as the most abundant $\mathrm{N}$ form in the xylem sap, representing $51.9 \%$ of the total sap nitrogen, whereas amino acids and ureides accounted for $41.2 \%$ and $6.6 \%$, respectively. Hence, it would appear that coffee plants have a high ability to partition absorbed nitrate and NRA between leaves and roots (Carelli and Fahl, 2005). In this sense, coffee trees differ from some other woody species, in which the nitrate influx into the leaf may be a major factor limiting the leaf NRA (Smirnoff and Stewart, 1985; Cruz et al., 1993; Lee and Titus, 1992; Gojon et al., 1994).

The balance of nitrate reduction between root and shoot is not necessarily constant for every species and may vary with plant growth conditions and plant development (Andrews, 1986). In fact, during coffee plant development the average NRA was higher in leaves than roots, however, the NRA leaf/root ratio ranged from 0.8 to 2.1 (Carelli and Fahl, 2005). These authors suggested that the observed variations in NRA leaf/root ratio was not related to changes in external nitrate availability nor plant development stages, as observed for other species (Andrews, 1986), but could be dependent on the irradiance levels (Carelli and Fahl, 2005). Under low irradiance $\left(290 \mu \mathrm{mol} \mathrm{m}^{-2} \cdot \mathrm{s}^{-1}\right)$ higher NRA was found in roots than leaves, and in contrast, plants grown under moderate irradiance $\left(720 \mu \mathrm{mol} \mathrm{m} \mathrm{m}^{-2} \cdot \mathrm{s}^{-1}\right)$ showed higher leaf NRA, while at high irradiance $\left(1540 \mu \mathrm{mol} \mathrm{m} \mathrm{m}^{-2} \cdot \mathrm{s}^{-1}\right)$ similar NRA values were found in leaves and roots. These findings could explain, at least in part, the contrasting data in the literature concerning the partitioning of NRA in coffee plants. In this sense, higher NRA was obtained in roots than leaves when experiments were conducted under low irradiance (Carelli et al., 1991; Queiroz et al., 1991,1993a; Carelli and Fahl, 2005), and vice-versa under higher irradiances (Carelli et al., 1990a; Da Matta et al. 1999, Amaral et al. 2001; Carelli and Fahl, 2005).

It has been suggested that when the photosynthesis is light-limited, increased nitrate assimilation in roots may 
allow greater control over the use of limited energy between nitrogen and carbon assimilation (Smirnoff and Stewart, 1985). In fact, Carelli and Fahl (2005) showed that nitrate reduction in roots was highest when plants were grown below the photosynthetic light saturation for coffee leaves, which range from $300 \mu \mathrm{mol} \mathrm{m} \mathrm{m}^{-2} \cdot \mathrm{s}^{-1}$ for shade-adapted plants to $600 \mu \mathrm{mol} \mathrm{m} \mathrm{m}^{-2} \cdot \mathrm{s}^{-1}$ for sun-adapted plants (Kumar and Tieszen, 1980; Fahl et al., 1994; Ramalho et al. 2000). On the other hand, leaf NRA was positively correlated with carbon assimilation $(\mathrm{r}=0.78, P<0.01)$ in response to irradiance regimes. Under intense shading carbon and nitrogen assimilation were limited in a similar way, while under moderate shading (around $800 \mu \mathrm{mol} . \mathrm{m}^{-2} \cdot \mathrm{s}^{-1}$ ), under which conditions both nitrate (Carelli et al. 1990b) and carbon assimilation are favored (Carelli et al., 1999), these two pathways achieved the highest values (Carelli and Fahl, 2005). These results emphasize that nitrate and carbon assimilation are highly coordinated in coffee leaves and respond to irradiance regimes, as previously documented for the ageing leaf (Fahl et al. 1992). Therefore, it would appear that in coffee, under conditions of maximum carbon assimilation, a higher proportion of nitrate would be assimilated in the leaves. In contrast, under limiting conditions for the photosynthetic process and consequently for leaf nitrate assimilation, higher NRA would occur in roots, compensating the diminished leaf NRA.

The contribution of shoot and roots to whole plant nitrate reduction depends on the relative size of each organ and varies with the age of each specific tissue. Taking into account these factors it was estimated by Queiroz et al. (1993a) that in young coffee plants growing under $85 \mu \mathrm{mol} \mathrm{m} \mathrm{m}^{-2} . \mathrm{s}^{-1}$ of irradiance level, leaves and roots contributed, respectively, with $43 \%$ and $52 \%$ of whole plant nitrate reduction. On the other hand, it was shown by Carelli (1987) and Carelli and Fahl (2005) that leaves are the main site of nitrate assimilation in young coffee plants grown under a moderate irradiance regime, contributing with $69.7 \%$ of the whole plant nitrate assimilation. Even under intense shading, when root NRA is $39 \%$ higher than leaf NRA, the shoot contribution would be also higher, since the young coffee plants showed 2.2-fold higher leaf fresh biomass compared to roots (Carelli and Fahl, 2005). Thus, under adequate irradiance levels for growth of coffee plants, leaves seem to be the main site of nitrate assimilation. This conclusion is in good agreement with the general proposal of Andrews (1986), suggesting that tropical wood species would carry out a substantial proportion of their nitrate assimilation in the shoots.

\section{Effect of tissue age on nitrate assimilation}

It is widely accepted that the ability of leaves and roots to reduce nitrate decreases with age (Schrader et al., 1974; Srivastava, 1980; Carelli and Magalhães, 1981; Kenis et al., 1992). Like in other species, leaf NRA in coffee plants is low during initial leaf expansion, reaches a peak in recently expanded leaves and declines in the older ones (Meguro and Magalhães, 1982; Carelli, 1987; Fahl et al., 1992; Queiroz et al., 1993a; Carelli and Fahl, 2005). However, this agedependent NRA decrease in coffee leaves was not as evident as in annual plants, since in the latter case very low NRA values were observed in older leaves (Schrader et al., 1974; Carelli and Magalhães, 1981). In the young coffee tree, a perennial evergreen species, older leaf NRA maintained nearly $70 \%$ of the values observed for recently expanded leaves, remaining nearly constant thereafter (Fahl et al. 1992; Carelli and Fahl, 2005). In addition, total $\mathrm{N}$ and chlorophyll content increased as the leaf expanded, remaining constant in mature leaves. All these results indicate that coffee leaves are able to maintain their metabolic activities for a longer period of time (Fahl, et al.1992).

During the initial six months of coffee plant development there is a synchronism in the NRA partition among the various leaf pairs. The initial NRA increase, as each leaf pair emerges, coincided with the peak of NRA in the subsequent older leaf pair. It is interesting to note that, although the NRA changed during each leaf development, the average shoot NRA remained nearly constant (Carelli and Fahl, 2005).

The NRA decrease with leaf aging has been correlated with the tissue's ability in synthesizing proteins (Wallace and Pate, 1965; Beevers and Hageman, 1969; Travis and Key, 1971). The lower NRA activity found in older leaves of corn is mainly due to a low level of NR-protein (Kenis et al., 1992). These authors suggested that the decreased ability of older leaves to form an active NR-protein in response to its substrate may be due to a decrease in NR-mRNA abundance with age (Kenis et al., 1992). On the other hand, the finding that NR-synthesis is dependent on the photosynthesis suggests that the fall in NRA in older leaves could also be related to the lower photosynthetic capacity (Kannangara and Woolhouse, 1967). That could also be the case in coffee plants, where a parallelism between NRA and photosynthesis is evident, in response to increasing leaf age (Fahl et al., 1992)

Coffee roots usually show a similar behavior as for leaves. Young root sections reduce nitrate more efficiently than mature tissues (Carelli et el., 1990a; Queiroz et al., 
1993a), independently of the carbohydrate and nitrate tissue level (Queiroz et al., 1993) and plant development stage (Carelli et al., 1990). In considering the whole root system, fine roots show higher NRA than the lateral roots, which exhibit higher NRA than the pivoting root (Carelli and Fahl, 2005).

\section{Physiologycal significance of root nitrate assimilation}

Considering the whole plant, roots are less efficient sinks than shoots. In coffee plants, when carbohydrate availability is a limiting factor, shoots compete with roots for photoassimilates, and roots are the first to reduce growth and generate less energy for metabolic processes (Cannell, 1975).

Nitrate assimilation in a heterotrophic organ such as the root requires metabolic energy and carbon skeletons supplied by sugar translocation from shoot. In coffee, root NRA and sugar content, mainly sucrose, decline rapidly after stem girdling or shoot excision (Carelli, 1987; Queiroz et al., 1992). Furthermore, nitrate reduction may be restored in roots of detopped coffee plants by the addition of sugar to the in vivo NRA assay (Queiroz et al., 1992). Nitrate absorption seems to be also sugar-limited in roots of coffee plants, however, to a lesser extent than root NRA (Carelli, 1987). All these results suggest that root nitrate assimilation in coffee plants is highly dependent on the continuous photosynthate supply and that the sugar reserves present in the roots are only sufficient to sustain nitrate reduction and active nitrate uptake for a short time period.

The effect of nitrate on roots is particularly complex because it induces increased NRA at the same time that it depletes the root's supply of sugar that supports nitrate assimilation (Radin et al., 1978). In coffee plants root growth and nitrate assimilation might compete for the available carbohydrates (Carelli and Fahl, 1991). In addition, the increase in external nitrate concentration induced larger increases in root NRA than leaf NRA (Carelli and Fahl, 1991), hence, causing a strong depletion of sugar content in the roots. In consequence, increasing nitrate availability for young coffee plants resulted in higher shoot/root biomass ratio (Carelli and Fahl, 1991).

As described earlier, coffee plants are capable of reducing nitrate in both leaves and roots (see Section 4). The balance of nitrate assimilation between leaves and roots is an important feature to consider in terms of energy cost at the whole plant level. In leaves, the reductant and ATP for nitrate reduction, and for the subsequent assimilation of ammonium into glutarate, is generated directly by photosynthesis (Beevers and Hageman, 1980; Cires et al, 1993). When nitrate assimilation takes place in the roots, high amounts of photosynthates must be transported to the roots and oxidized to provide the required reductants, energy and carbon skeletons. Consequently, the energy cost of leaf nitrate assimilation is about half to a quarter of the root assimilation cost (Schrader and Thomas, 1981; Smirnoff et al., 1984). The energy cost of root assimilation would be further increased if compounds such as asparagine and allantoin/allantoic acid were the major forms of organic nitrogen translocated to the leaves, which is the case of coffee plants (Mazzafera and Gonçalves, 1999). This is because in order to make the nitrogen in these compounds available for the synthesis of amino acids they must first be catabolized, released as ammonium and reassimilated in the leaves (Smirnoff et al., 1984).

All these findings considered together may have some important agronomical consequences. In Brazil, coffee is traditionally cultivated under full sunlight, but seedlings are produced in nurseries under shade conditions. Due to the higher energetic cost of root nitrate assimilation, environmental nursery conditions favoring nitrate assimilation in roots, such as high nitrate availability (Carelli and Fahl, 1991) and/or intense shading (Carelli and Fahl, 2005), may cause higher shoot development, in relation to roots. This enhanced shoot/root biomass ratio may be unfavorable when seedlings are transferred to the field, where they will be submitted to high irradiance-temperature regimes and eventually low water availability. In this situation, the relatively smaller roots will not provide the plants with enough water and nutrients to maintain shoot turgor and vigor. On the other hand, appropriate $\mathrm{N}$ fertilization is particularly important in the nursery, since this nutrient is believed to be a key factor for plants to endure and counteract the photoinibitory effects that occur when young coffee plants are transferred to the open field (see Section 7).

\section{Seasonal changes in nitrate assimilation}

During the annual reproductive cycle, coffee plants usually exhibit changes in nitrate uptake (Carvajal et al., 1969; Cannell and Kimeu, 1971) and assimilation capacity (Taleisnik el al., 1980; Carelli et al., 1989) which have been associated with the several developmental stages of flowers and fruits. In Costa Rica, Carvajal et al. (1969) observed that nitrate uptake rate of mature coffee plants, growing in nutrient solution, was higher before anthesis and 
at the beginning of fruit maturation. Similarly, Carelli et al. (1989) found that leaf NRA in coffee-trees growing in Brazil under natural light-temperature regimes and constant nitrate supply in nutrient solution, showed higher values prior to anthesis and at the end of fruit development. Such results indicate that the differential nitrate uptake, associated with the phenological phases, might be an important factor in the control of leaf NRA during the annual cycle of the mature coffee tree, independent of the variations promoted by seasonal environmental conditions (Carelli et al. 1989).

Both phenological phases, in which coffee plants present higher leaf NRA values, are coincident with the periods of intense metabolite and nutrient demand from the sinks (flowers and fruits). The first is the late phase of flower development (Taleisnik et al. 1980; Carelli et al., 1989), when the flower buds rapidly expand and show an expressive increase in dry matter, requiring rapid metabolite transport from the nearest photosynthesizing leaves (Barros et al., 1982). The second is the late phase of fruit development, when seed endosperms are in formation, which are powerful sinks of carbohydrates and minerals (Cannell, 1975).

In accordance, coffee trees (or branches) bearing fruits exhibited higher leaf NRA than the deblossomed ones (Taleisnik et al. 1989; Carelli et al., 1989; Amaral et al., 2001). Leaf nitrate concentrations followed the same trend of NRA suggesting that there is a preferential course of nutrient flow to the higher consuming branches (sink strength) (Cannell and Kimeu, 1971; Taleisnik et al., 1980; Carelli et al., 1989).

Coffee fruits during their rapid expansion phase may draw over $95 \%$ of the current total uptake of $\mathrm{N}$ (Cannell, 1985), often causing $\mathrm{N}$ deficiency symptoms in foliage and restricting vegetative growth (Amaral et al., 2001). Besides, Cannell (1971) observed that photosynthetic rate was higher in fruiting trees than in deblossomed ones.

On the other hand, root NRA apparently is not influenced by the presence of fruits. Amaral et al. (2001) reported that coffee roots, although containing more nitrate than leaves, showed much lower NRA and were not affected by fruiting.

Variations in the environmental conditions may also contribute to changes in the nitrate assimilation capacity of coffee trees during the annual cycle. Taleisnik et al. (1980), in Costa Rica, observed that leaf NRA presented seasonal variations correlated with rainfall regime and with the soil and plant water contents, with higher NRA values found during the dry season, when plants were in the flowering and maturing stages. In contrast, it was observed in Brazil that the highest leaf NRA and leaf nitrate concentration occurred during the warm and wet season, when periods of high air temperature and high evaporative demand also occur (Da Matta et al., 1999; Amaral et al., 2001). Such conditions led to an increase in the water inflow, and consequently to an enhanced nitrate influx to the leaves, which in turn brought about a rise in NRA (Da Matta et al., 1999; Amaral et al., 2001).

In hot sunny weather, even coffee trees growing under high water availability may exhibit increased internal resistance to water movement, except in genotypes tolerant to high irradiance-temperature regimes (Cannell, 1975; Carelli et al., 1989). In fact, most coffee genotypes presently cultivated in Brazil were obtained by genetic breeding under full sunlight and wide spacing, and maintain high stomatal conductance and transpiration rates even under high irradiance-temperature regimes, when water availability is not limiting (Carelli et al., 1999; Fahl et al., 2001). In addition, maximum air temperature in traditional coffee growing regions of Costa Rica and Brazil (ca. $34^{\circ} \mathrm{C}$ ) does not appear to affect the seasonal trends of NRA in both leaves and roots (Taleisnik et al. 1989; Carelli et al., 1989; Amaral et al., 2001). On the other hand, periods of low air temperature during the annual cycle of the coffee tree seemed to adversely affect leaf nitrate assimilation. In Brazil, regardless of the $\mathrm{N}$ fertilization, leaf NRA was apparently null in the cool season (May to September) with temperatures around $15^{\circ} \mathrm{C}$ at 09 : $00 \mathrm{~h}$, while root NRA was sustained by $\mathrm{N}$ supplementation during the cold period (Amaral et al., 2001).

\section{Photoprotective role of nitrogen under photoinhibitory conditions}

As stated above, Coffea arabica L. grows naturally in shaded habitats and bears some physiological and structural characteristics of a shade plant (Rhizopoulou and Nunes, 1981). This results in severe photoinhibition when exposed to high irradiance, namely when young plants are transferred from nursery into open field. Since the cultivation of coffee without shading is becoming very attractive worldwide, due to higher potential production, the ability of coffee to avoid photodamage is an important issue in coffee production and has encouraged research into technological and genetic improvements to overcome the problems resulting from exposure to high light.

It is well known that exposure of leaves to light levels higher than those that can be used in photosynthesis, that is, when the rate of transfer of excitation energy from the 
antennae to the photochemical reaction centres exceeds the rate of transfer from those reaction centres to the electron transport chain, may cause photoinhibition (Young and Britton, 1990). It is now evident that photoinhibition, which results from the conjunction of excessive light energy pressure with other stress factors, like drought, chilling, etc., has an important impact under natural conditions.

Overexcitation of the photosynthetic apparatus and photoinhibition can occur in nature due to changes in light irradiance, namely when plants are exposed to diurnal and seasonal variations, when the inner part of a canopy is briefly exposed to high irradiance, or even when the plants are exposed to moderate levels of light coexisting with other stresses (e.g., low temperature or water shortage). Under excess of light energy photooxidative stress may occur due to an accumulation of excited molecules (e.g., $\left.{ }^{3} \mathrm{chl} *,{ }^{1} \mathrm{chl},{ }^{1} \mathrm{O}_{2}\right)$ in the pigment bed and the overreduction of $\mathrm{O}_{2}$, leading to the formation of $\mathrm{O}_{2}{ }^{-}$. In chloroplasts, under normal metabolic conditions, the production of $\mathrm{O}_{2}{ }^{--}$is controlled and almost restricted to PSI, through the pseudocyclic electron flow, also known as the Mehler reaction. However, under stress conditions their production may increase and the photoproduction of ${ }^{1} \mathrm{O}_{2}$ and $\mathrm{O}_{2}{ }^{\cdot-}$ (that in turn promotes the production of $\mathrm{H}_{2} \mathrm{O}_{2}$ and $\cdot \mathrm{OH}$ ) can also occur at the PSII level, if photoinhibition at the PSII donor side arises (Lidon and Henriques, 1993; Asada, 1994; Foyer et al., 1994). These highly reactive chemical entities may cause damage, namely lipid peroxidation, bleaching of pigments (e.g., in $P_{680}$ ), protein degradation (e.g., D1), enzyme inactivation and even DNA damage (Asada and Takahashi, 1987; Winston, 1990; Barber and De Las Rivas, 1993; Foyer et al., 1994; Niyogi, 1999), resulting in impaired membrane functionality and lower ability of photon-use and enhanced photoproduction of reactive molecules (Asada, 1994).

To prevent oxidative stress at the chloroplast level, due to the production of active forms of oxygen and chl, plants have evolved complex systems to remove such highly reactive chemical entities at their generation site. For that, the over-expression of antioxidative scavengers, such as enzymes (e.g., superoxide dismutase, ascorbate peroxidase), and hydrophilic (e.g., ascorbate, glutathione) and lipophilic (e.g., zeaxanthin, $\beta$-carotene and $\alpha$-tocopherol) antioxidants, is of great importance (Foyer et al., 1994; Adams and Barker, 1998; Strand et al., 1999; Adams et al., 2002; Munné-Bosch, 2005).

It has been demonstrated that the pathways of carbon and nitrogen metabolism are clearly interdependent. The photosynthetic electron transport associated with carbon metabolism is the driving force for both of these processes (Huppe and Turpin, 1994, Foyer et al., 1995) and carbon assimilation products have regulatory functions over the activity of nitrate reductase (Cires et al., 1993). Furthermore, a close relation between light-saturated photosynthetic rate in air and $\mathrm{N}$ content of leaves is widely recognized (Evans, 1989), explained by the fact that leaf $\mathrm{N}$ is essentially allocated to photosynthetic components. On the other hand, $\mathrm{N}$ limitation imposes a reduction in the cellular concentration of pigments, photosynthetic units and Calvin cycle enzymes, which in turn causes a decrease in the capacity for carbon assimilation (Sukenik et al., 1987) and thereby a higher sensitivity to photoinhibition. Consequently, any given irradiance is potentially in greater excess under conditions of $\mathrm{N}$ deficiency (Verhoeven et al., 1997).

Thus, a higher $\mathrm{N}$ content might allow for better photosynthetic performance (Hikosaka and Terashima, 1995) and consequently it is expected that $\mathrm{N}$ fertilization would improve plant performance under suboptimal conditions. In fact, nitrogen fertilization, applied in a broad range of doses, has positive effects on growth and may improve plant performance in conditions such as marginal temperature (Lawlor et al., 1987), high light (Osmond, 1987; Ferrar and Osmond, 1986; Algarra and Rudiger, 1993) and shortage of water (Shimshi 1970, Bennett et al., 1986). Under stress conditions, higher $\mathrm{N}$ availability was observed to trigger photoprotective mechanisms in C. arabica (Fahl et al., 1994; Ramalho et al., 1998, 1999, 2000) and to promote osmotic adjustment and an increase in the long term water use efficiency due to improved carbon assimilation in $C$. canephora (Da Matta et al., 2002).

Plants may be able to acclimate photosynthesis to different light intensities by triggering some protective mechanisms, which are regarded as responses to shortterm high irradiance exposure and as acclimation when related to long-term high irradiance exposure, which implies marked adjustments in the structures and composition of the photosynthetic apparatus (Ferrar and Osmond, 1986; Evans, 1989; Seemann, 1989; Long et al., 1994). Since N availability is particularly important for protein synthesis, the level of $\mathrm{N}$ nutrition will determine photosynthetic shade to sun acclimation as well as sensitivity to and recovery from photoinhibition (Ferrar and Osmond, 1986; Ramalho et al., 1998, 2000).

Recent studies with young ( $c a .1 .5$ years old) Coffea arabica plants, emphasize an interesting ability to acclimate 
to high irradiance, both on a short-term (Ramalho et al., 1997) and a long-term basis (Fahl et al., 1994; Ramalho et al., 1998; Ramalho et al., 1999), if appropriate $\mathrm{N}$ nutrition were provided. The observed N-dependent photosynthetic performance and acclimation was a consequence of several processes with their own characteristic time responses. First, it should be noted that higher $\mathrm{N}$ availability promoted a better general status of the plant before exposure to high $P P F D$. Support for this conclusion was obtained through the higher values of some gas exchange (e.g., $\left.A_{\max }, F\right)$ and fluorescence (e.g., $F_{\mathrm{v}}{ }^{\prime} / F_{\mathrm{m}}, f_{\mathrm{e}}$ ) parameters, levels of photosynthetic pigments (both chlorophylls and carotenoids) and protein and TFA (Ramalho et al., 1998, 2000) associated with changes in leaf morphological features and chloroplast ultrastructure (Fahl et al., 1994).

Nevertheless, independent of $\mathrm{N}$ availability, all plants were affected at the beginning of the imposed high irradiance period, both in the photochemical and enzymatic processes of photosynthesis, reaching their lowest performance usually around the $3^{\text {rd }}$ to $7^{\text {th }}$ day of high PPFD exposure. However, the plants with higher $\mathrm{N}$ availability were less affected, both during the first hours (Ramalho et al., 1997) and until the $3^{\text {rd }}$ to $7^{\text {th }}$ day (Nunes et al., 1993; Ramalho et al., 2000), showing that the reported better status helped of those plants helped to endure the stress during the initial phase. Evidence for this were the higher values obtained for photochemical efficiency of PSII $\left(F_{\mathrm{v}} / F_{\mathrm{m}}\right.$ and $\left.F_{\mathrm{v}}{ }^{\prime} / F_{\mathrm{m}}{ }^{\prime}\right)$, electron transport $\left(q_{\mathrm{P}}, f_{\mathrm{e}}\right.$ and $\left.J_{\text {max }}\right)$, carboxylation activity of rubisco and photosynthetic rates ( $A$ and $A_{\max }$ ) (Nunes et al., 1993; Ramalho et al., 1997; 1999; 2000). Such improved photosynthetic performance was also due to the triggering of some protective and repair processes. Among these we would underline the increase in content of the xanthophyll cycle pigments, namely zeaxanthin (Ramalho et al., 1997, 2000), responsible for energy dissipation in the photosystems and the increase of de novo synthesis of protein (Nunes et al., 1993; Ramalho et al., 1997), indispensable for the repair of photodamaged structures.

After the initial shock phase, $\mathrm{N}$ availability promoted the recovery of the photosynthetic machinery, since plants with higher $\mathrm{N}$ nutrition presented a complete (or almost complete) recovery of several photosynthetic parameters. Such a response was observed for the in vivo parameters, $A$, $A_{\text {max }}, J_{\text {max }}, V_{\text {cmax }}, F_{\mathrm{v}} / F_{\mathrm{m}}, F_{\mathrm{v}}{ }^{\prime} / F_{\mathrm{m}}{ }^{\prime}, q_{\mathrm{P}}, f_{\mathrm{e}}$ (Nunes et al., 1993; Ramalho et al., 2000) as well as for the in vitro electron transport rates around PSII, rubisco content and activity, and $Q_{\mathrm{A}}$ content (Ramalho et al., 1999). Furthermore, only these plants showed an increase in the $P P F D$ required to saturate $A$ and to obtain $A_{\text {max }}$, to irradiance levels close to those used to impose the stress (Ramalho et al., 2000). Such improved photosynthetic functioning would reduce the overreduction of the electron transport chain and the overacidification of the thylakoids lumen, which are known sensitive factors for photooxidative damage of PSII (Müller et al., 2001) and PSI (Sonoike, 1996; 1999).

As in other tropical plants subjected to excessive energy levels (Sonoike, 1996, 1999; Kudoh e Sonoike, 2002), the PSI constituted a preferential photoinhibitory target in all $\mathrm{N}$ treatments, as inferred from the decrease in the $c h l a / b$ ratio and in $\beta$-carotene. These changes were interpreted to indicate a preferential photobleaching of PSI chlorophyll (Williams et al., 1986; Miller and Carpentier, 1991) and a decrease in PSI complex (Schäfer and Schmidt, 1991; Schmidt and Schäfer, 1994), with which most of the leaf $\beta$-carotene is associated (Miller and Carpentier, 1991), and is in agreement with the observed loss of cyt $b_{6}$ and $f$ (Nunes et al., 1993; Ramalho et al., 1998, 1999). Nevertheless, such effects did not limit the photosynthetic rates in plants with higher $\mathrm{N}$ availability, which presented a complete recovery after 2 weeks of high irradiance exposure.

On the other hand, the plants with lower (and intermediate) $\mathrm{N}$ availability showed low rubisco activity together with strong negative effects, both in the light harvesting and electron transport processes, namely in the antennae $\left(F_{\mathrm{o}}\right), O E C$, $P S I I$ photochemical efficiency and activity, and the cyt $b_{6}$ and $f$ contents, which suggests the presence of both a donor and an acceptor side photoinhibition of PSII. In these plants the effects at the PSI level further constituted a major limiting step for thylakoid electron transport and $\mathrm{CO}_{2}$ assimilation. In view of these results it was not surprising that some "global" gas exchange and fluorescence parameters presented strong negative effects, namely $A, A_{\max }, J_{\max }, V_{\text {cmax }}$ and $q_{\mathrm{P}}$, with some of these effects being detected from the very beginning of high irradiance exposure (Nunes et al., 1993; Ramalho et al., 1997, 1999, 2000).

The reported recovery in the plants with higher $\mathrm{N}$ availability was supported, at least partly, by dissipative mechanisms, which constitute adjustments of the efficiency of light harvesting and primary photochemistry and will act against photo-oxidative damage. That was observed through the presence of higher contents of zeaxanthin, lutein and $\beta$-carotene, a high DEPS throughout the stress period and a strong $q_{\mathrm{NP}}$ and $q_{\mathrm{E}}$ observed by the end of stress (Ramalho et al., 2000). They operate mainly through thermal 
dissipation and are determinant for the photoprotection of the photosynthetic apparatus (Ma et al., 2003). Zeaxanthin and lutein transform ${ }^{1} \mathrm{chl}$ to $\mathrm{chl}$ with heat production, while $\beta$-carotene removes ${ }^{3} \mathrm{chl}$ and ${ }^{1} \mathrm{O}_{2}$, producing $c h l, \mathrm{O}_{2}$ and ${ }^{3} \mathrm{Car}$, the latter dissipating the excitation energy through heat (Siefermann-Harms, 1987; De Las Rivas et al., 1993; Niyogi et al., 1997; Niyogi, 1999; Foyer, 2002). Concomitantly, the non-photochemical quenching and its main component, $q_{\mathrm{E}}$, related to the energy state of thylakoid membranes, also perform thermal dissipation of excess energy. That process involves conformational changes of the $L H C$ and requires the presence of some xanthophylls (zeaxanthin, lutein) and of PsbS protein from PSII (Li et al., 2000; Müller et al., 2001; Külheim et al., 2002).

Furthermore, the reinforcement of ascorbate peroxidase and glutathione reductase activities (Ramalho et al., 1998) would promote detoxification of active oxygen species through the direct control of $\mathrm{H}_{2} \mathrm{O}_{2}$ levels.

Altogether, these mechanisms effectively alleviated the energetic overcharge in the photosystems and protected them against highly reactive molecules of chl and oxygen. That allowed the maintenance of a lower reduction state of the electron transport chain, as observed by the higher oxidized state of the $Q_{\mathrm{A}}$ pool (higher $q_{\mathrm{P}}$ ) and sustained the higher photosynthetic rates shown by the plants with higher $\mathrm{N}$ availability, which in turn would have contributed to the reduced leakage of electrons towards oxygen, decreasing the $\mathrm{O}_{2}{ }^{\circ-}$ production rate (Ramalho et al., 1998). In fact, such higher utilization of energy through photochemistry denotes better functioning of the photosynthetic apparatus and constitutes the best protection against further photoinhibition.

The above mentioned photoprotective processes and the better photosynthetic performance promoted by a higher $\mathrm{N}$ availability presumably give the plants the time required to develop some more permanent (structural) readjustments at the chloroplast level. In fact, after about 2 weeks of high irradiance exposure, clear quantitative and qualitative changes were observed that represent acclimation features with characteristics similar to those displayed by sun plants, thereby allowing the plants to cope with the new irradiance conditions. These changes included decreases in the investment in light harvesting pigments, namely $\mathrm{chl}$ and some carotenoids (Nunes et al., 1993; Ramalho et al., 2000) which will reduce the collected energy and thus the energetic pressure over the photosystems. Also, the decrease in $\operatorname{chl} / \mathrm{N}$ and $\alpha / \beta$ carotene ratios, the increase in N-protein/total $\mathrm{N}$ and total carotenoid/ total chl ratios (Nunes et al., 1993; Ramalho et al., 2000), the higher investment in stromal versus thylakoid components (increases of the rubisco/chl ratio and of rubisco content) (Ramalho et al., 1999), indicates changes towards an acclimation (Lichtenthaler et al., 1983; Hikosaka and Terashima, 1995; Logan et al., 1996) in the plants with higher (and to some extent with intermediate) $\mathrm{N}$ availability. Finally, the changes in the TFA of chloroplast lipids and the increase of the saturation level, mainly due to a preferential synthesis of $C 16: 0$ relative to $C 18: 3$ (Ramalho et al., 1998), enhance chloroplast membrane stability and preserve the photosynthetic processes (Raison et al., 1982; Hugly et al., 1989), as well as decreasing membrane susceptibility to photooxidative stress (Pham Thi et al., 1990; Paula et al., 1993).

From the above discussion it can be concluded that the level of $\mathrm{N}$ nutrition clearly determines whether acclimation to high irradiance may take place or not in C. arabica (cv. Catuaí). Indeed higher $\mathrm{N}$ availability clearly alleviated photoinhibitory impact from the first day, allowing recovery, usually after the $3^{\text {rd }}$ to $7^{\text {th }}$ day, and promoted the photosynthetic acclimation after about 2 weeks of high irradiance exposure, both in the photochemical and carboxylation reaction components. As part of the acclimation process $\mathrm{N}$ promoted a better initial status of the photosynthetic apparatus before the stress was imposed, and during stress imposition promoted the ability to undergo biochemical/structural changes involving membrane lipid characteristics and the reinforcement of the antioxidative mechanism.

Acknowledgements: The work from J. D. C. Ramalho was partially supported through the project POCTI/AGG/ 43101/ 2001, co-financed by the Foundation for Science and Technology, Portugal, and the European fund FEDER. M.L.C. Carelli and J. I. Fahl thank Consócio Brasileiro de Pesquisa e Desenvolvimento do Café (CBP\&D/Café) for finantial support.

\section{REFERENCES}

Adams III WW and Barker DH (1998) Seasonal changes in xanthophyll cycle-dependent energy dissipation in Yucca glauca Nuttall. Plant Cell Environ. 21:501-511.

Adams III WW, Demmig-Adams B, Rosenstiel TN, Brightwell AK and Ebbert V (2002) Photosynthesis and photoprotection in overwintering plants. Plant Biol. 4:545-557.

Algarra P, Rüdiger W (1993) Acclimation processes in the light harvesting complex of the red alga Porphyridium purpureum (Bory) Drew et Ross according to irradiance and nutrient availability. Plant Cell Environ. 16:149-159.

Alves JD, Cordeiro AT, Rena AB (1985) Relações entre fotossíntese, resistência difusiva e variação circadiana da redutase do nitrato em Coffea arabica L. In: Anais do $12^{\circ}$ Congresso Brasileiro de Pesquisas Cafeeiras, Caxambu, Brasil, pp.142-145. 
Amaral JAT, Da Matta FM, Rena AB (2001) Effects of fruiting on the growth of arabica coffee trees as related to carbohydrate and nitrogen status and to nitrate reductase activity. Braz. J. Plant Physiol. 13:66-74.

Andrade Netto JF (2005) Atividade das enzimas redutase do nitrato e glutamina sintetase em cafeeiro arábica. Piracicaba, Escola Superior de Agricultura "Luiz de Queiroz", Universidade de São Paulo. MSc thesis.

Andrews SM (1986) The partitioning of nitrate assimilation between root and shoot of higher plants. Plant Cell Environ. 9:511-519.

Asada K (1994) Mechanisms for scavenging reactive molecules generated in chloroplasts under light stress. In: Baker N R and Bowyer J R (eds), Photoinhibition of photosynthesis - From molecular mechanisms to the field, pp.129-142. BIOS Scientific Publishers Ltd., Oxford, England.

Asada K, Takahashi M (1987) Production and scavenging of active oxygen in photosynthesis. In: Kyle DJ, Osmond CB and Arntzen CJ (eds.), Photoinhibition, Topics in photosynthesis, Vol 9, pp.227-287. Elsevier Science Publishing, B.V. Amsterdam, The Netherlands.

Barber J, De Las Rivas J (1993) A functional model for the role of cytochrome $b_{559}$ in the protection against donor and acceptor side photoinhibition. Proc. Natl. Acad. Sci. USA 90:10942-10946.

Barros RS, Maestri M, Moreira RC (1982) Sources of assimilates for expanding flower buds of coffee. Turrialba 32 : 371-377.

Bennet JM, Jones JW, Zur B, Hammond LC (1986) Interactive effects of nitrogen and water stresses on water relations of field-grown corn leaves. Agron. J. 78:273-280.

Beevers L, Hageman RH (1969) Nitrate reduction in higher plants. Ann. Rev. Plant Physiol. 20:495-522.

Beevers L, Hageman RH (1980) Nitrate and nitrite reduction. In: Stumpf, P.K., Conn, E.E. (eds.), The Biochemistry of Plants, pp.115-168. Academic Press, New York, USA.

Cannell MGR (1975) Crop physiological aspects of coffee bean yield: a review. J. Coffee Res. 5:7-20.

Cannell MGR (1985) Physiology of coffee crop. In: Clifford MN, Wilson KC (eds), Coffee: botany, biochemistry and production of beans and beverage, pp.109-134. Croom Helm, New York, U.S.A.

Cannell MGR, Kimeu BS (1971) Uptake and distribution of macro-nutrients in trees of Coffea arabica L. in Kenya as affected by seasonal climatic differences and the presence of fruits. Ann. Appl. Biol 68:213-230.

Carelli MLC (1987) Estudo do processo de redução de nitrato durante o desenvolvimento inicial e no estádio reprodutivo de plantas de café (Coffea arabica L.). Campinas, Universidade Estadual de Campinas. PhD thesis.

Carelli, MLC; Magalhães AC (1981) Development of nitrate reductase activity in green tissues of soybean seedlings (Glycine max L. Merr.). Z. Pflanzenphysiol. 104:17-24.

Carelli MLC, Fahl JI (2000). Crecimiento y asimilación del carbono y nitrógeno en plantas jóvenes de Coffea en condiciones de sol y de sombra. In: Memoria del XIX Simposio Latinoamericano de Caficultura. San José, Costa Rica, pp.101-108.
Carelli MLC, Fahl JI (2005). Partitioning of nitrate reductase activity and its relation to carbon assimilation under different irradiance regimes. Submitted for publication Environ. Exp. Bot.

Carelli MLC, Fahl JI, Magalhães AC (1989) Assimilação de nitrato durante o desenvolvimento reprodutivo de plantas de café. Rev. bras. Ci. Solo 13:59-64.

Carelli MLC, Fahl JI, Magalhães AC (1990a) Atividade da redutase de nitrato em folhas e raízes de plantas de café. Rev. brasil. Bot. 13:119-123.

Carelli MLC, Fahl JI, Magalhães AC (1990b) Redução de nitrato em plantas jovens de café cultivadas em diferentes níveis de luz e de nitrogênio. Bragantia 50, 27-37.

Carelli MLC, Fahl JI (1991) Distribuição da assimilação de nitrato e de matéria seca em plantas jovens de café cultivadas em diferentes níveis de nitrogênio. Bragantia 50:29-37.

Carelli MLC, Fahl JI, Trivellin PCO, Queiroz-Voltan RB (1999) Carbon isotope discrimination and gas exchange in Coffea species grown under different irradiances regimes. Braz. J. Plant Physiol. 11:63-68.

Carelli MLC, Fahl JI, Alfonsi, EL, Magossi, R, Pezzopane, JRM, Ramalho, JC (2001) Trocas gasosas fotossintéticas e densidade de fluxo de seiva em plantas de Coffea arabi$c a$ cv. Obatã em diversos regimes de irradiância. In: Resumos do VIII Congresso Brasileiro de Fisiologia Vegetal, Ilhéus, Brazil (extended abstract in CD-ROM).

Carvajal JF, Acevedo A, Lopez CA (1969) Nutrient uptake by the coffee tree during a yearly cycle. Turrialba 19:13-20.

Catani, RA, Moraes FRP (1958). A composição química do cafeeiro. Rev. de Agric. 33:45-52.

Cires A, Torre A, Delgado B, Lara C (1993) Role of light and $\mathrm{CO}_{2}$ fixation in the control of nitrate-reductase activity in barley leaves. Planta 190:277-283.

Cordeiro AT, Rena AB, Mendes LF, Alves JD, Pereira AA (1984) Atividade da redutase do nitrato em plantas jovens e adultas de Coffea arabica L., à luz e na obscuridade. In: Annals of the $11^{\circ}$ Congresso Brasileiro de Pesquisas Cafeeiras, Londrina, Brasil, pp.77-79.

Cruz CM, Soares MIM, Martins-Loução MA (1991) Nitrate reduction in seedlings of carob (Ceratonia siliqua L.). New Phytol. 119:413-419.

Cruz CM, Lips SH, Martins-Loução, MA (1993) Nitrogen assimilation and transport in carob plants. Physiol. Plant. 89:524-531.

Da Matta FM (2004) Ecophysiological constraints on the production of shaded and unshaded coffee: a Review. Field Crops Res. 86:99-114.

Da Matta FM, Amaral JAT, Rena AB (1999) Growth periodicity in trees of Coffea arabica L. in relation to nitrogen supply and nitrate reductase activity. Field Crops Res. 60: 223-229.

Da Matta FM, Loos RA, Silva EA, Loureiro ME, Ducatti C (2002) Effects of soil water deficit and nitrogen nutrition on water relations and photosynthesis of pot-grown Coffea canephora Pierre. Trees 16:555-558.

De Las Rivas J, Telfer A, Barber J (1993) Two coupled betacarotene molecules protect $\mathrm{P} 680$ from photodamage in iso- 
lated photosystem two reaction centres. Biochim. Biophys. Acta 1142:155-164.

Evans JR (1989) Photosynthesis and nitrogen relationships in leaves of $\mathrm{C}_{3}$ plants. Oecologia 78:9-19.

Fahl JI, Carelli MLC, Magalhães AC (1992) Asimilación de carbono y nitrógeno en hojas de café. Turrialba 42:523527.

Fahl JI, Carelli MLC, Vega J, Magalhães AC (1994) Nitrogen and irradiance levels affecting net photosynthesis and growth of young coffee plants (Coffea arabica L.). J. Hort. Sci. 69:161-169.

Fahl JI, Carelli MLC, Menezes HC, Gallo PB, Trivelin PCO (2001) Gas exchange, growth and beverage quality of $C o f$ fea arabica cultivars grafted on to C. canephora and C. congensis. Exp. Agric. 37:241-252.

Faleiros RRS, Melo WJ, Carvalho F, Miranda Neto AT (1975) Atividade da nitrato redutase e desenvolvimento de mudas de Coffea arabica L. (café). Científica 3:277-283.

Ferrar PJ, Osmond CB (1986) Nitrogen supply as a factor influencing photoinhibition and photosynthetic acclimation after transfer of shade-grown Solanum dulcamara to bright light. Planta 168:563-570.

Foyer CH (2002) The contribution of photosynthetic oxygen metabolism to oxidative stress in plants. In: Inzé D, Van Montag M (eds), Oxidative Stress in Plants, pp.33-68. Taylor \& Francis, London, England.

Foyer CH, Lelandais M, Kunert KJ (1994) Photooxidative stress in plants. Physiol. Plant. 92:696-717.

Foyer CH, Valadier MH, Ferrario S (1995) Co-regulation of nitrogen and carbon assimilation in leaves. In: Smirnoff $\mathrm{N}$ (ed), Environment and Plant Metabolism - Flexibility and Acclimation pp.17-33. Environmental Plant Biology Series, Bios Scientific Publishers, Oxford, England.

Gojon A, Plassard C, Bussi C (1994) Root/shoot distribution of $\mathrm{NO}_{3}{ }^{-}$assimilation in herbaceous and woody species. In: Garnier, RJ E. (ed), A Whole Plant Perspective on Carbonnitrogen Interactions, pp.131-147. SPB Academic Publishing, The Hague, The Netherlands.

Gojon A, Bussi C, Grignon C, Salsac L (1991). Distribution of $\mathrm{NO}_{3}{ }^{-}$reduction between roots and shoots of peach-tree seedlings as affected by $\mathrm{NO}_{3}{ }^{-}$uptake rate. Physiol. Plant. 82:505-512.

Hikosaka K, Terashima I (1995) A model of the acclimation of photosynthesis in the leaves of $\mathrm{C}_{3}$ plants to sun and shade with respect to nitrogen use. Plant Cell Environ. 18: 605-618.

Hugly S, Kunst L, Browse J, Somerville C (1989) Enhanced thermal tolerance of photosynthesis and altered chloroplast ultrastructure in a mutant of Arabidopsis deficient in lipid unsaturation. Plant Physiol. 90:1134-1142.

Huppe HC, Turpin DH (1994) Integration of carbon and nitrogen metabolism in plant and algal cells. Annu. Rev. Plant Physiol. Plant Mol. Biol. 45:577-607.

Kaiser WM, Hubber SC (2001) Post-translational regulation of nitrate reductase: mechanism, physiological relevance and environmental triggers. J. Exp. Bot. 52:1981-1989.

Kannangara CG Wollhouse HW (1967) The role of carbon dioxide, light and nitrate in the synthesis and degradation of nitrate reductase in leaves of Perilla frutescens. New Phytol. 66:553-561.

Kenis JD, Silvent ST, Luna CM, Campbell WH (1992) Induction of nitrate reductase in detached corn leaves: the effect of the age of the leaves. Physiol. Plant. 85:49-56.

Klepper L, Hageman RH (1969) The occurrence of nitrate reductase in apple leaves. Plant Physiol. 44:110-114.

Kudoh H, Sonoike K (2002) Irreversible damage to photosystem I by chilling in the light: cause of the degradation of chlorophyll after returning to normal growth temperature. Planta 215:541-548.

Külheim C, Ågren J, Jansson S (2002) Rapid regulation of light harvesting and plant fitness in the field. Science 297: 91-93.

Kumar D, Tieszen LL (1980) Photosynthesis in Coffea arabica. I. Effects of light and temperature. Exp. Agr. 16:13-19.

Lawlor DW, Boyle FA, Kendall AC, Keys AJ (1987) Nitrate nutrition and temperature effects on wheat: enzyme composition, nitrate and total amino acid content of leaves. J. Exp. Bot. 38:378-392.

Lee HJ, Titus JS (1992) Nitrogen accumulation and nitrate reductase activity in MM.106 apple trees as affected by nitrate supply. J. Hort. Sci. 67:273-281.

Leece DR, Dilley DR, Kenworth AL (1972) The occurrence of nitrate reductase in leaves of Prunus species. Plant Physiol., 49:725-728.

Lillo C (1994) Light regulation of nitrate reductase in green leaves of higher plants: Minireview. Physiol. Plant. 90: 616-620.

Li X-P, Björkman O, Shih C, Grossman AR, Rosenquist M, Jansson S, Niyogi KK (2000) A pigment-binding protein essential for regulation of photosynthetic light harvesting. Nature 403:391-395.

Lichtenthaler HK, Burgstahler R, Buschmann C, Meier D, Prenzel U, Schönthal A. (1983) Effect of high light and high light stress on composition, function and structure of the photosynthetic apparatus. In: Marcelle R, Clijsters H, Poncke M Van (eds), Effects of Stress on Photosynthesis - Advances in Agricultural Biotechnology', pp.353-370. Martinus Nijhoff, Dr. W. Junk Publishers: The Hague, The Netherlands.

Lidon FC, Henriques FS (1993) Oxygen metabolism in higher plant chloroplasts. Photosynthetica 29:249-279.

Logan BA, Barker DH, Demmig-Adams B, Adams III WW (1996) Acclimation of leaf carotenoid composition and ascorbate levels to gradients in the light environment within an Australian rainforest. Plant Cell Environ. 19: 1083-1090.

Long SP, Humphries S, Falkowski PG (1994) Photoinhibition of photosynthesis in nature. Ann. Rev. Plant Physiol.Plant Mol. Biol. 45:633-662.

Malavolta E (1986) Nutrição, adubação e calagem para o cafeeiro. In: Rena AB, Malavolta E, Rocha M, Yamada T (eds), Cultura do Cafeeiro: Fatores que Afetam a Produtividade, pp.165-274. POTAFOS, Piracicaba, Brasil.

Mazzafera P, Gonçalves KV (1999) Nitrogen compounds in the xylem sap of coffee. Phytochemistry 50:383-386. 
Ma Y-Z, Holt NE, Li X-P, Niyogi KK, Fleming G.R. (2003) Evidence for direct carotenoid involvement in the regulation of photosynthetic light harvesting. Proc. Natl. Acad. Sci. USA, 100:4377-4382.

Meguro NE, Magalhães AC (1982) Atividade da redutase de nitrato em cultivares de café. Pesq. Agrop. bras. 17:17251731.

Miller N, Carpentier R (1991). Energy dissipation and photoprotection mechanisms during chlorophyll photobleaching in thylakoid membranes. Photochem. Photobiol. 54: 465-472.

Müller P, Li X.-P, Niyogi K (2001) Non-photochemical quenching. A response to excess light energy. Plant Physiol. 155:1558-1566.

Munné-Bosch S (2005) The role of $\alpha$-tocopherol in plant stress tolerance. J. Plant Physiol. 162:743-748.

Nazareno RB, Oliveira CAS, Sanzonowicz C, Sampaio JBR, Silva JCP, Guerra AF (2003) Crescimento inicial do cafeeiro Rubi em resposta a doses de nitrogênio, fósforo e potássio e a regimes hídricos. Pesq. Agrop. Bras. 38:903-910.

Niyogi KK (1999) Photoprotection revisited: genetic and molecular approaches. Annu. Rev. Plant Physiol. Plant Mol. Biol. 50:333-359.

Niyogi KK, Björkman O, Grossman A (1997) The roles of specific xanthophylls in photoprotection. Proceedings of the National Academy of Sciences USA 94:14161-14167.

Noctor G, Foyer CH (1998) A re-evaluation of the ATP: NADPH during $\mathrm{C}_{3}$ photosynthesis: a contribution from nitrate assimilation and its associated respiratory activity? J. Exp. Bot. 49:1895-1908.

Nunes MA, Ramalho JC, Dias MA (1993) Effect of nitrogen supply on the photosynthetic performance of leaves from coffee plants exposed to bright light. J. Exp. Bot. 44: 893-899.

Oaks A (1994) Primary nitrogen assimilation in higher plants and its regulation. Can. J. Bot. 72:739-750.

Olsson MO, Falkengren-Grerup U (2003) Partitioning of nitrate uptake between trees and understory in oak forests. Forest Ecol. Manag. 179:311-320.

Osmond CB (1987) Photosynthesis and carbon economy of plants. New Phytol. 106 (Suppl.):161-175.

Paula FM, Pham-Thi AT, Zuily-Fodil Y, Ferrari-Iliou R, Vieira da Silva J, Mazliak P (1993) Effects of water stress on the biosynthesis and degradation of polyunsaturated lipid molecular species in leaves of Vigna unguiculata. Plant Physiol. Biochem. 31:707-715.

Pham Thi AT, Vieira da Silva J, Mazliak P (1990) The role of membrane lipids in drought resistance of plants. Bull. Soc. Bot. Fr., Actual. Bot. 137 :99-114.

Queiroz CGS, Alves JD, Rena AB, Cordeiro AT (1991) Efeito do cloranfenicol, propanol, $\mathrm{pH}$ e temperatura sobre a atividade da redutase do nitrato em cafeeiros jovens. Rev. bras. Bot. 14:73-77.

Queiroz CGS, Rena AB, Cordeiro AT, Alves JD (1992) Efeitos da excisão da parte aérea, remoção de folhas e anelamento do caule sobre a atividade da redutase do nitrato nas raízes do cafeeiro. Rev. Bras. Fisiol. Veg. 4:55-57.
Queiroz CGS, Rena AB, Cordeiro AT, Alves JD (1993a) Distribuição da atividade da redutase do nitrato no cafeeiro: a importância da raiz. Rev. bras. Bot. 16:31-35.

Queiroz CGS, Rena AB, Cordeiro AT, Alves JD (1993b) Ritmo diurno na atividade da redutase de nitrato em folhas e raízes de Coffea arabica L. Pesq. Agrop. bras. 28:787-795.

Radin JW (1978) A physiological basis for the division of nitrate assimilation between roots and leaves. Plant. Sci. Lett. 13: 21-25.

Radin JW, Parker LL, Sell CS (1978) Partitioning of sugar between growth and nitrate reduction in cotton roots. Plant Physiol. 57:55-58.

Raison JK, Roberts JK, Berry JA (1982) Correlation between the thermal stability of chloroplast (thylakoid) membranes and the composition and fluidity of their polar lipids upon acclimation of higher plant Nerium oleander to growth temperature. Biochem. Biophys. Acta 688:218-288.

Ramalho JC, Pons TL, Groeneveld HW, Nunes MA (1997) Photosynthetic responses of Coffea arabica leaves to a short-term high light exposure in relation to $\mathrm{N}$ availability. Physiol. Plant. 101:229-239.

Ramalho JC, Campos PS, Teixeira M, Nunes MA (1998) Nitrogen dependent changes in antioxidant systems and in fatty acid composition of chloroplast membranes from Coffea arabica L. plants submitted to high irradiance. Plant Science 135:115-124.

Ramalho JC, Campos PS, Quartin VL, Silva MJ, Nunes MA (1999) High irradiance impairments on photosynthetic electron transport, ribulose-1,5-bisphosphate carboxylase/ oxigenase and $\mathrm{N}$ assimilation as a function of $\mathrm{N}$ availability in Coffea arabica L. plants. J. Plant Physiol. 154:319-326.

Ramalho JC, Pons TL, Groeneveld HW, Azinheira HG, Nunes, MA (2000) Photosynthetic acclimation of high light conditions in mature leaves of Coffea arabica L.: role of xanthophylls, quenching mechanisms and nitrogen nutrition. Aust. J. Plant Physiol. 27:43-51.

Rhizopoulou S, Nunes MA (1981) Some adaptative photosynthetic characteristics of a sun plant (Ceratonia siliqua) and a shade plant (Coffea arabica). In: Margaris NS, Mooney HA (eds), Components of Productivity of MediterraneanClimate Regions. Basic and Applied Aspects, pp.85-89. Dr W Junk Publisher, The Hague, The Netherlands.

Schäfer C, Schmidt E (1991) Light acclimation potential and xanthophyll cycle pigments in photoautotrophic suspension cells of Chenopodium rubrum. Physiol. Plant. 82: 440-448.

Schrader LE Thomas RJ (1981) Nitrate uptake, reduction and transport in the whole plant. In: Bewley, J.D. (ed), Nitrogen and carbon metabolism, pp.49-93. Martinus Nijhoff / Dr Junk Publishers, The Hague, The Netherlands.

Schmidt E, Schäfer C (1994) Alterations of the chlorophyllprotein pattern in chronically photoinhibited Chenopodium rubrum cells. Planta 192:473-479.

Schrader LE, Cataldo DA, Peterson DM, Vogelzang RD (1974) Nitrate reductase and glucose-6phosphate dehydrogenase activities as influenced by leaf age and addition of protein to extraction media. Physiol. Plant. 32:337-341. 
Seemann JR (1989) Light adaptation/acclimation of photosynthesis and the regulation of ribulose-1,5-bisphosphate carboxylase activity in sun and shade plants. Plant Physiol. 91:379-386.

Sgherri CLM, Pinzino C, Navari-Izzo F (1996) Sunflower seedlings subjected to increasing stress by water deficit: Changes in $\mathrm{O}_{2}{ }^{--}$production related to the composition of thylakoid membranes. Physiol. Plant. 96:446-452.

Shimshi D (1970) The effect of nitrogen supply on some indices of plant water relations of beans (Phaseolus vulgaris L.). New Phytol. 69:413-424.

Siefermann-Harms D (1987) The light-harvesting and protective functions of carotenoids in photosynthetic membranes. Physiol. Plant. 69:561-568.

Smirnoff N, Stewart GR (1985) Nitrate assimilation and translocation by higher plants: comparative physiology and ecological consequences. Physiol. Plant. 64:133-140.

Smirnoff N, Todd P, Stewart GR (1984) The occurrence of nitrate reduction in leaves of wood plants. Ann. Bot. 54: 363-374.

Solomonson LP, Braker MJ (1990) Assimilatory nitrate reductase: functional properties and regulation. Ann. Rev. Plant Physiol. Plant Mol. Biol. 41:225-253.

Sonoike K (1996) Photoinhibition of photosystem I: its physiological significance on the chilling sensitivity of plants. Plant Cell Physiol. 37:239-247.

Sonoike K (1999) The different roles of chilling temperatures in the photoinhibition of photosystem I and photosystem II. J. Photochem. Photobiol. B: Biol. 48:136-141.

Srivastava HS (1980) Regulation of nitrate reductase activity in higher plants. Phytochemistry 19:725-733.

Strand $\AA$, Hurry V, Henkes S, Huner N, Gustafsson P, Gardeström P, Stitt M (1999) Acclimation of Arabidopsis leaves developing at low temperatures. Increasing cytoplasmic volume accompanies increased activities of enzymes in the Calvin cycle and in sucrose-biosynthesis pathway. Plant Physiol. 119:1387-1397.
Sukenik A, Bennett J, Falkowski P (1987) Light-saturated photosynthesis - limitation by electron transport or carbon fixation. Biochim. Biophys. Acta 891:205-215.

Taleisnik E, Briceño JA, Carvajal JF (1980) Variación estacional de la reductasa de nitrato em el cafeto. Turrialba 30:330-337.

Thomas FM, Hilker C (2000) Nitrate reduction in leaves and roots of young pedunculate oaks (Quercus robur) growing on different nitrate concentrations. Environ. Exp. Bot. 43:19-32.

Travis RL, Key JL (1971) Correlation between polyribosome level and the ability to induce nitrate reductase in dark grown corn seedlings. Plant Physiol. 48:617-620.

Verhoeven AS, Demmig-Adams B, Adams III W.W. (1997) Enhanced employment of the xanthophyll cycle and thermal energy dissipation in spinach exposed to high light and N stress. Plant Physiol. 113:817-824.

Voltan RBQ, Fahl JI, Carelli MLC (1992) Variação na anatomia foliar de cafeeiros submetidos a diferentes intensidades luminosas. Braz. J. Plant Physiol. 4:99-105.

Wallace W, Pate JS (1965) Nitrate reductase in field pea (Pisum arvense L.). Ann. Bot. 29:655-671.

Williams WP, Sen A, Fork DC (1986) Selective photobleaching of PSI-related chlorophylls in heat-stressed pea chloroplasts. Photosynth. Res. 10:75-92.

Winston GW (1990) Physiochemical basis for free radical formation in cells: Production and defenses. In: Alscher RG, Cumming JR (eds), Stress Responses in Plants: Adaptation and Acclimation Mechanisms. pp.57-86. Plant Biology Series, Vol. 12. Wiley-Liss, New York. USA.

Willson KC (1985) Mineral nutrition and fertilizer needs. In: Clifford MN, Willson KC (eds), Coffee Botany, Biochemistry and production of beans and beverage, pp.135-156. Croom Helm, London.

Young AJ, Britton G (1990) Carotenoids and Stress. In: Alscher RG, Cumming JR (eds), Stress Responses in Plants: Adaptation and Acclimation Mechanisms, pp.87-112. Wiley-Liss Inc. New York. USA. 